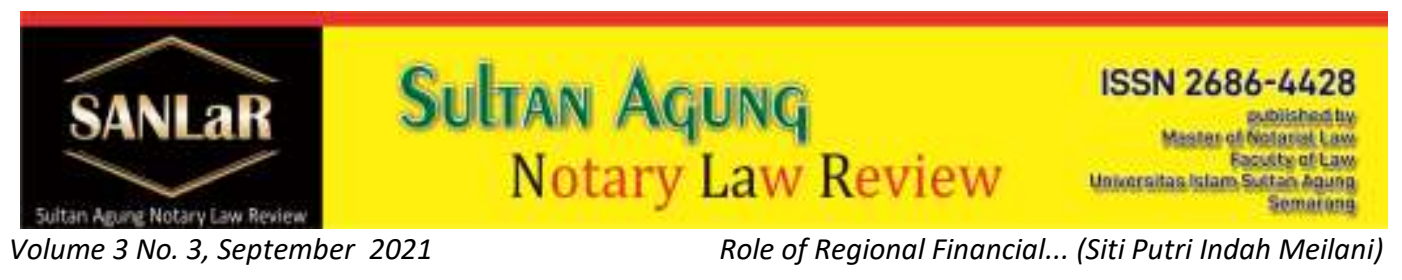

\title{
Role of Regional Financial \& Assets Management Agency (BPKAD) in the Mediation Process of BPHTB \& PPH
}

\author{
Siti Putri Indah Meilani ${ }^{*}$ ) \\ ${ }^{*}$ Faculty of Law, Universitas Islam Sultan Agung (UNISSULA) Semarang, E-mail: \\ imeilani961@gmail.com
}

\begin{abstract}
Abtract. The research "The Role of the Regional Financial and Asset Management Agency (BPKAD) in the Mediation Process for Determining the Fee for Land and Building Rights/Income Tax (BPHTB/PPH) in Pati Regency" is motivated by myths that develop in the community regarding land ownership rights. This study aims to: 1) identify and analyze the role of BPKAD in Pati Regency. 2) knowing and analyzing the mediation process for determining BPHTB/PPH in Pati Regency. The research method in this thesis uses a sociological juridical approach with descriptive analysis specifications, namely data collection methods to obtain data that will be used as thesis material through interviews by conducting interviews with BPKAD Pati Regency, or by observation in the form of observations involved systematically in obtaining data. After that, qualitative analysis of the data obtained from various sources will be carried out. The results of the study indicate that: 1) BPKAD has not carried out its functions and roles as public servants properly. 2) The mediation process will be carried out between the seller and the buyer and BPKAD as the mediator.
\end{abstract}

Keywords: Role; Notary; Mediation; BPKAD; BPHTB; PPH.

\section{Introduction}

Pati is one of the regencies in Central Java Province which has an area of 1,504 $\mathrm{km} 2$. This district is famous for its motto Pati Bumi Mina Tani. The population of Pati Regency was $1,259,590$ people at the end of 2019. Administratively since 2006 Pati Regency consists of 21 Districts, 401 Villages, and 5 villages are referred to by another name (hereinafter referred to as village) is a legal community unit that has territorial boundaries and is authorized to regulate and manage the interests of the local community based on local origins and customs that are recognized and respected in the Government System of the Unitary State of the Republic of Indonesia. Indonesia (Act No. 32 of 2004). 
The importance of plots of land for everyone for their ownership, not only urban people but also for rural people even in any country today. Especially in future developments, where population growth compared to the available land is very worrying for the owner, because it will become a potential conflict if it is based on customary law (unwritten law). In this regard, a rule is stipulated that in order to guarantee legal certainty by the government a "land registration" is held throughout the territory of the Republic of Indonesia, the result of which is a certificate as strong evidence of its control over certain land parcels.

Even though the people of Pati Regency are modern, they still believe in the myths that have developed in society so far. One of the myths that the people of Pati Regency still believe is about the purchase of land. The land referred to here is the land that is directly opposite the end of the intersection. This myth is believed by the people of Pati if the land is built a house, then the owner of the house will often get sick. Meanwhile, if the house is used for businesses such as shops, then the business will not succeed and go bankrupt.

According to the government, the land has a high selling value because it is in a strategic position. The land does not have a high selling value for the local community. Usually the people who buy it are not used for housing or shopping businesses, the land is usually used for gardens or left alone.

The problem that will be examined in this paper is related to the determination of the sale and purchase tax of the land. Where the location of the land at the intersection has a high selling price for buying and selling taxes according to the Regional Financial and Asset Management Agency (BPKAD) of Pati Regency but has a low selling price for the local community, so people think they have a low sales tax. Cases like this often occur in Pati Regency. Where when there will be a sale and purchase of land by the buyer using the services of a notary who then submits it to the Regional Financial and Asset Management Agency (BPKAD) Pati Regency. When a notary submits the amount of sale and purchase tax that has been previously agreed upon by the land buyer to take care of the transfer of rights, The Regional Financial and Asset Management Agency (BPKAD) of Pati Regency uses the national sales tax collection standard which is still high in value. So this is often a problem. When this problem arose, mediation was carried out by the parties, where the Regional Financial and Asset Management Agency (BPKAD) of Pati Regency became the mediator in solving the problem.

\section{Research Methods}

The approach method used in this research is sociological juridical. The sociological juridical aspect used in this research is the legislation and legal certainty related to the role of BPKAD and the mediation process.

The data used in this study is primary data. The primary data in this study were obtained through interviews with the Pati Regency BPKAD and the people who felt the impact of the mediation. In addition to primary data, this study also uses 
secondary data consisting of primary legal materials, secondary legal materials, and tertiary legal materials to support primary data.

This study uses a qualitative data analysis method, namely the data obtained during the research process and then systematically compiled and analyzed so as to achieve clarity on the issues discussed, namely the role of the Regional Financial and Asset Management Agency (BPKAD) in the mediation process for determining the Customs Fee. Land and Building/Income Tax (BPHTB/PPH) in Pati Regency.

\section{Results and Discussion}

3.1. The Role of the Regional Financial and Asset Management Agency (BPKAD) of Pati Regency

The Regional Financial and Asset Management Agency (BPKAD) of Pati Regency was established in 2007 and began operating on March 3, 2009. At its inception, the Regional Financial and Asset Management Agency was an agency that had been established based on Pati Regency Regulation Number 11 of 2008 Chapter XI Article 29 concerning the Organization and Work Procedures of the Pati Regency Regional Office. However, in early 2017 the policy was changed and the Regional Revenue, Financial and Asset Management Office was changed to the Regional Financial and Asset Management Agency based on Regent Regulation Number 62 of 2016 and Regional Regulation Number 13 of 2016 concerning the formation and composition of regional apparatus. This change does not have a major impact on the main tasks and functions of the Pati Regency Financial and Asset Management Agency.

BPKAD is the implementing element of the supporting functions in the financial sector and co-administration tasks. To act as a technical policy maker for supporting elements of regional government affairs in the field of Financial Management and Regional Assets, carrying out technical tasks for government affairs, monitoring and evaluating the implementation of technical tasks. BPKAD is a public service agency.

As the regional general treasurer, the BPKAD is a technical service that is responsible for receiving regional revenues and disbursing money for regional needs through the regional general treasury. With the regional treasury, a region regulates the availability of sufficient funds to fund regional expenditures. In the regional general treasury it can also be known how much wealth an area has. The regional treasury itself is contained in the comparative balance which is part of the financial statements.

Financial assets are all forms of government assets in the form of cash and other assets that can be converted into cash and cash equivalents within a period of twelve months from the reporting date. Meanwhile, tangible non-financial assets are inventories and fixed assets. Fixed assets themselves are usually better known as regional or state property. 
According to Act No. 32 of 2004 article 1 paragraph 5, regional autonomy is the right, authority and obligation of an autonomous region to regulate and manage its own government affairs and the interests of the local community in accordance with statutory regulations. While fiscal decentralization is the transfer of authority to local governments to manage regional financial financing to meet the needs of local government administration.

Based on the understanding of the state, etymologically, state power can be interpreted as "the ability of the organization of social life in an area to force all existing social groups and groups legally based on legal provisions to achieve the goals of common life that have been determined previously".

According to Act No. 25 of 2009 concerning Public Services

Public service providers, hereinafter referred to as Providers, are state administration institutions, corporations, independent institutions established by law for public service activities, and other legal entities established solely for public service activities.

Implementers of public services, hereinafter referred to as Implementers, are officials, employees, officers, and everyone who works within the organizing organization in charge of carrying out an action or series of public service actions.

Service standard is a benchmark that is used as a guideline for service delivery and a reference for evaluating service quality as an obligation and promise of the organizer to the community in the context of quality, fast, easy, affordable, and measurable services.

Service notice is a written statement that contains all the details of the obligations and promises contained in the service standard. Public service information system, hereinafter referred to as Information System, is a series of activities that include the storage and management of information as well as a mechanism for delivering information from the organizers to the public and vice versa in spoken form, Latin writing, writing in Braille, picture language, and/or local language, and presented manually or electronically.

In this case, BPKAD has not carried out its role as a public servant because it has not carried out its role properly and has not carried out its functions.

Principles of public service implementation:
a. Public interest
b. Legal certainty
c. equal rights
d. balance of rights and obligations 


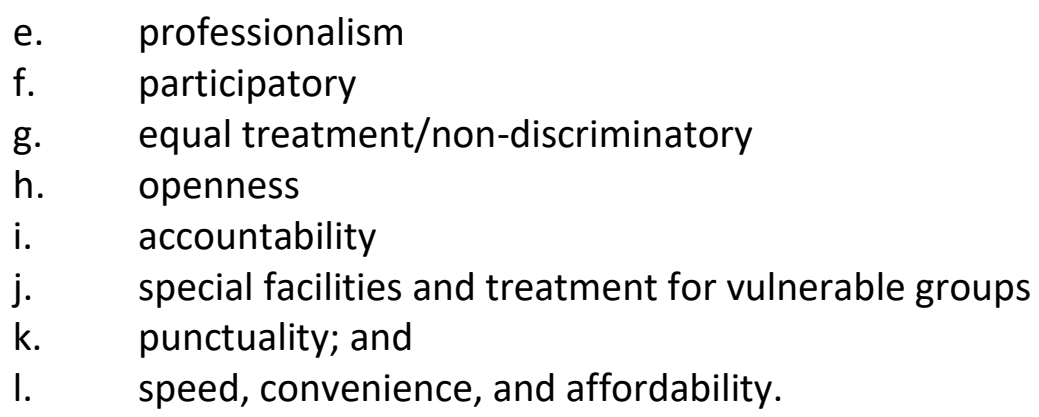

Role theory emphasizes the nature of the individual as a social actor who studies behavior according to the position he occupies in the work environment and society. The role referred to in this study is a person's behavior according to his status in society. BPKAD as an agency that acts as a public servant should be able to play a role and serve the community, both in information disclosure or public services without being kept secret because information disclosure is the right of the community.

\subsection{Mediation Process in Determining BPHTB/PPH in Pati regency}

Based on Act No. 25 of 2009 concerning Public Services, Mediation is the settlement of public service disputes between parties through assistance, either by the ombudsman himself or through a mediator formed by the ombudsman. The dispute resolution process is through a process of negotiation or consensus of the parties, assisted by a mediator who does not have the authority to decide or impose a settlement. The main characteristic of the mediation process is negotiation, which is essentially the same as the process of deliberation or consensus.

Mediation is a peaceful process in which the disputing parties submit their settlement to a mediator to achieve a fair final result, without wasting too much cost but still effective and fully accepted by both parties to the dispute voluntarily.

\section{Mediation Process:}

1) The Parties agree to mediate, because mediation is voluntary in nature

2) Selection of the mediator, which is carried out by the disputing parties.

3) Mediator meeting with the disputing parties, the meeting is held by the mediator separately from one party to another.

Mediation phase:

a. Identify and explain problems and problems.

b. Conduct a summary of the problems and create an agenda for discussion.

c. Discuss each problem one by one.

d. Readiness to solve problems. 
e. Cooperation solves problems.

f. Make a written agreement.

The mediation process outside the court is not regulated in laws and regulations, the regulation is only limited to the use of mediation, but not about the process of organizing mediation. Therefore the mediation process is based on the experience of mediation practitioners and research by experts. The absence of regulation of the mediation process in the law is both a strength and a weakness of the mediation process. The absence of setting the stage of mediation is seen as a mediating strength because it provides flexibility for the parties and the mediator. To organize the mediation process according to the needs of the parties according to the type of problem in the case. Referred to as a weakness because the absence of regulation shows the absence of standardization and certainty. The mediation process is basically not regulated in laws and regulations,

Based on the theory of legal systems according to Friedmen used in analyzing this problem are:

a Legal Substance

- $\quad$ Act No. 28 of 2009 concerning Regional Taxes and Regional Levies

- $\quad$ Regional Regulation Number 3 of 2011 concerning Regional Taxes

b. Legal Structure, the part that handles mediation if there are problems with BPHTB is the PBB and BPHTB

c. Legal Culture

BPKAD employees are less willing to be open about the technical process of mediation to the public. People tend to obey the government because they are worried that there will be problems when processing land certificates.

The theory of the operation of the law, elements outside the legal system that influence positive law in Pati Regency are customary/customary laws that have been in effect for a long time in Pati Regency. However, BPKAD employees do not use this customary/custom law in solving problems.

After the author conducted research to BPKAD on Thursday, August 12 at 12.00 WIB with the BPKAD, the part that handled mediation and BPHTB. The BPKAD was reluctant to provide information about the mediation process for determining the BPHTB, because according to BPKAD the title of the research taken by the author was too specific and the BPKAD could not fulfill the data requested by the author.

In addition to BPKAD, the author also conducted interviews with the residents concerned with the mediation conducted by the Pati Regency BPKAD in May 
2021 at the residence of Mr. Sudiawan. According to Mr. Sudiawan's statement, the BPKAD was not cooperative regarding the basis used for determining the BPHTB. According to his statement, when the seller and buyer have agreed on the land price and BPHTB tax, there is no need for mediation anymore because it will increase the costs of the parties and will take time. Problems like this often make people lazy to take care of buying and selling taxes at the BPKAD office because the process is less effective and efficient.

\section{Closing}

BPKAD is the implementing element of the supporting functions in the financial sector and co-administration tasks. To act as a technical policy maker for supporting elements of regional government affairs in the field of Financial Management and Regional Assets, carrying out technical tasks for government affairs, monitoring and evaluating the implementation of technical tasks. BPKAD is a public service agency. BPKAD as a public service agency has not been able to carry out its role properly as regulated in Act No. 25 of 2009 concerning Public Service. The mediation process that occurred within the BPKAD of Pati Regency was due to differences in BPHTB/PPH proposed by the seller and buyer with the provisions of BPKAD. According to the parties who have agreed on the land price and tax, there is no need for mediation because it will take time and cost. The mediation was attended by both the seller and the buyer with BPKAD as the mediator.

\section{References}

Journals:

[1] A Chuasanga, Ong Argo Victoria. (2019). Legal Principles Under Criminal Law in Indonesia Dan Thailand, Jurnal Daulat Hukum, Vol 2, No 1 (2019) http://jurnal.unissula.ac.id/index.php/RH/article/view/4218

[2] Alam, Bahrul., \& Khisni, Akhmad. (2020). Legal Protection of Holders of Land Loss Data In The City Land Office of Kendari. JURNAL AKTA: Vol.7, No. 2, 159-164. Retrieved from http://jurnal.unissula.ac.id/index.php/akta/article/view/7963

[3] Arrohim, Mohammad B., \& Wahyuningsih, Sri Endah. (2020). Analysis of Judicial Application of Criminal Penalty Against Notary / Land Deed Officials Conducting Making Crime of the Fake Authentic Deed in State Court of Semarang. JURNAL AKTA: Vol.7, No. 2, 183-188. Retrieved from http://jurnal.unissula.ac.id/index.php/akta/article/view/7891

[4] Deen, Thaufiq., Ong Argo Victoria \& Sumain. (2018). Public Notary Services In Malaysia. JURNAL AKTA: Vol. 5, No. 4, 1017-1026. Retrieved from http://jurnal.unissula.ac.id/index.php/akta/article/view/4135 
[5] Ong Argo Victoria, (2018) Waqf Al-Nuqūd In Indonesia (In Law Perspective), Jurnal Pembaharuan Hukum Vol 5, No 1 Universitas Sultan Agung, http://jurnal.unissula.ac.id/index.php/PH/article/view/2999

[6] Sukarmi, S., \& Victoria, A. (2018). Cash Waqf in Sustaining Of Indonesian Society "In Legal \&amp; Economic Perspective". AL-ITQAN: JOURNAL OF ISLAMIC SCIENCES AND COMPARATIVE STUDIES, 2(1), 83-97. https://doi.org/10.31436/al-itqan.v2i1.43

[7] Victoria, O. A., \& ., M. (2021). Doctor's Constributions in Transportation Monitoring During COVID-19 Pandemic. KnE Social Sciences, 5(1), 598618. https://doi.org/10.18502/kss.v5i1.8317

[8] Hartanto, H.; Victoria, O.A.; Chuasanga, A. Maritime Transportation in Indonesian Policy. J. Pembaharuan Huk. 2019, 6, 36-44, Jurnal Pembaharuan Hukum Unissula, Vol. 6, No. 1 (2019), http://jurnal.unissula.ac.id/index.php/PH/article/view/4657

Books:

[1] Bambang Sunggono, 2003, Metode Penelitian Hukum, PT. Raja Grafindo, Jakarta

[2] Beni Ahmad Saebani, 2008, Metode Penelitian, Pustaka Setia, Bandung

[3] H. Jawade Hafidz Arsyad, 2013, Korupsi Dalam Perspektif HAN, Sinar Grafika, Jakarta

[4] Juhaya S. Praja, 2011, Teori Hukum dan Aplikasinya, Ed. I, CV Pustaka Setia, Bandung

[5] Mahkamah Agung RI, 2004, Mediasi dan Perdamaian, mimeo

[6] Marihot P. Siahaan,2003, Bea Perolehan Hak Atas Tanah dan Bangunan, Raja Grafindo Persada, Jakarta 